\title{
The BMJ should not narrowly confine publication to positivist quantitative studies
}

\author{
Fiona Webster associate professor \\ University of Toronto, 500 University Avenue, Toronto, ON, Canada M5G 1V7
}

I am disappointed in the official response by the editors of The $B M J .{ }^{12}$ I am fortunate enough to be a member of a community of research scientists who are largely trained in social science approaches, such as critical qualitative research, at the University of Toronto in Canada (Centre for Critical Qualitative Research and the Wilson Centre for Education Research). Qualitative research as a broad category refers to or draws on many academic disciplines, including sociology, philosophy, and anthropology, to name just a few, not to mention centuries of academic thought.

The sociologist Max Weber argued that research is scientific if it offers a systematic approach to researching questions and problems. Such a definition does not favour one set of methods, methodologies, or paradigms over another. It is simply unreasonable to categorise all qualitative research as "exploratory" and dismiss its contributions as not being "generalisable." The power of critical qualitative research lies in the theoretical and conceptual insights it generates. Moreover, many qualitative researchers do not work in isolation but rather in conversation with researchers who specialise in other methodologies. This is what makes its findings transferable, relevant, and transformative.

Moreover, the notion that evidence produced through positivist scientific methods is enough to "change clinical practice and help doctors make better decisions"- the stated criteria The $B M J$ editors have chosen to adopt - has been shown to be erroneous many times over. The decision to publish research should be based on standards of excellence and rigour appropriate to each approach and not be narrowly confined to positivist quantitative studies alone.

Competing interests: None declared.

Greenhalgh T, Annandale E, Ashcroft R, et al. An open letter to The BMJ editors on qualitative research. BMJ 2016;352:i563. doi:10.1136/bmj.i563. 26865572.

2 Loder E, Groves T, Schroter S, Merino JG, Weber W. Qualitative research and The BMJ. BMJ 2016;352:i641. doi:10.1136/bmj.641. 26865061.

Published by the BMJ Publishing Group Limited. For permission to use (where not already granted under a licence) please go to http://group.bmj.com/group/rights-licensing/ permissions 